\title{
MECHANICAL ANALYSIS OF CLAMP FOR POWERLINE CONDUCTORS
}

\author{
PAULECH Juraj ${ }^{1}$, KUTIŠ Vladimír ${ }^{1}$, GÁLIK Gabriel ${ }^{1}$, MURÍN Justín ${ }^{1}$ \\ ${ }^{I}$ STU - Slovak University of Technology, Faculty of Electrical Engineering and Information Technology, \\ Department of Applied Mechanics and Mechatronics, Ilkovičova 3, 81219 Bratislava, Slovakia \\ e-mail: juraj.paulech@stuba.sk,vladimir.kutis@stuba.sk,gabriel.galik@stuba.sk,justin.murin@stuba.sk
}

Abstract: The contribution deals with mechanical simulation of clamps for overhead powerline AlFe conductors. The process of pressed joint creation for two AlFe conductors and tensile test of such system are simulated using ANSYS software. The obtained results are compared to given tensile strength of the clamp.

KEYWORDS: AlFe conductor, Clamp, Mechanical simulation, Tensile strength

\section{Introduction}

Overhead powerline AlFe conductor is aluminium conductor steel reinforced with stranded layers of steel (inner layers) and aluminium (outer layers) wires of circular cross-section. Each wire layer has opposite lay direction in comparison with adjacent layers. Series connection of two conductors is provided by pressed joint using conductor clamp. Simulation of pressed joint creation and tensile test for AlFe 350/59 and clamp type 166635 are presented in this contribution, the models of conductor and camp used for simulations are shown in Fig. 1.

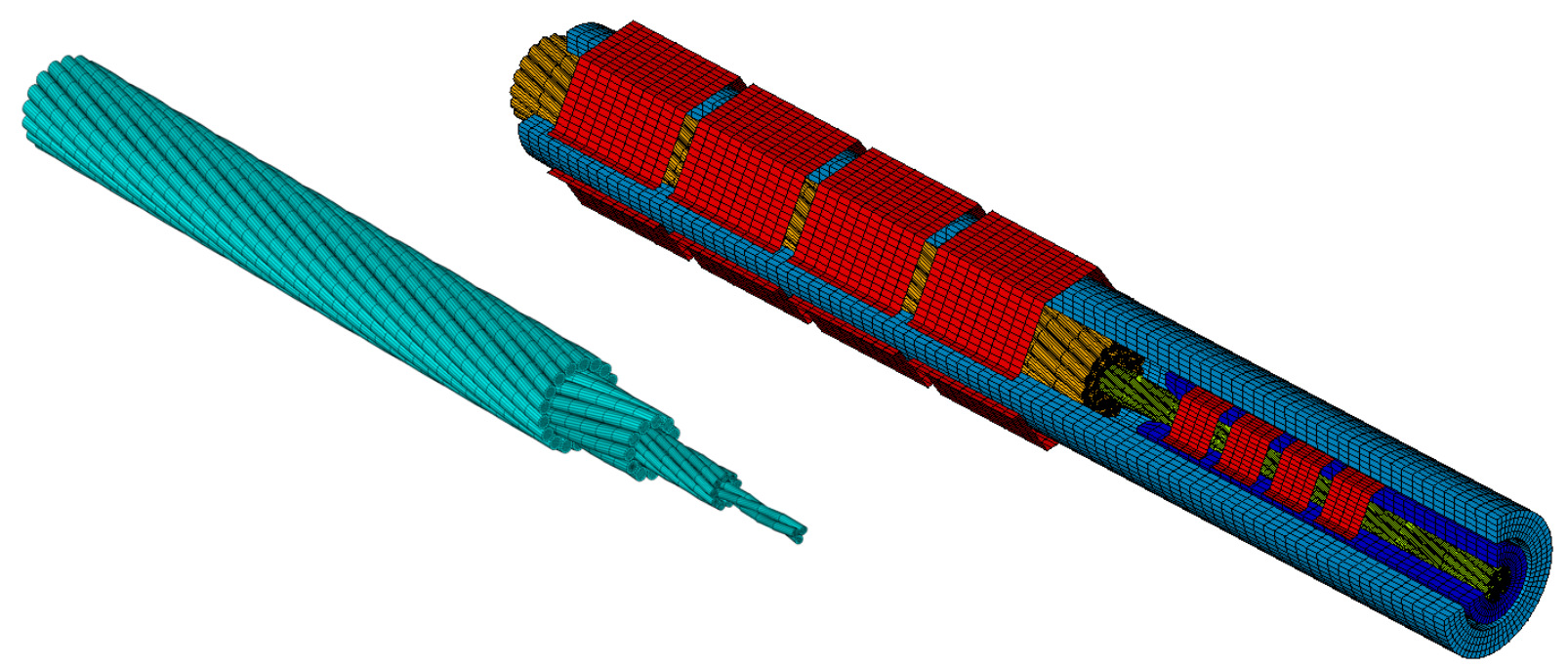

Fig. 1 Model of AlFe 350/59 (left) and process of pressed joint creation using the clamp type 166635 - half of the clamp in cross-section view with only one conductor (right)

The AlFe conductor has 2 steel $(3+9$ wires $)$ and 2 aluminium $(11+17$ wires $)$ layers with wires of 2.50 and $4.00 \mathrm{~mm}$ in diameter respectively. Each layer has different lay ratio (the $1^{\text {st }}$ layer: $12.55,2^{\text {nd }}: 11.71,3^{\text {rd }}: 13.00,4^{\text {th }}: 11.50$ ) and alternating lay direction, the last (top) layer has right-hand lay direction. The overall diameter of the conductor is $26.39 \mathrm{~mm}$. Rated tensile strength is over $127 \mathrm{kN}[1,2,3]$. 
The clamp consists of two parts: steel core has length of $250 \mathrm{~mm}\left(\mathrm{a}_{1}\right)$, outer diameter is $24 \mathrm{~mm}\left(\mathrm{D}_{1}\right)$ and the bore is $11 \mathrm{~mm}$; aluminium shell is $700 \mathrm{~mm}$ long $\left(\mathrm{a}_{2}\right)$, outer diameter is $45 \mathrm{~mm}\left(\mathrm{D}_{2}\right)$ and the bore is $28 \mathrm{~mm}$, see Fig. 2. Rated tensile strength is $100 \mathrm{kN}[4,5,6,7,8]$.

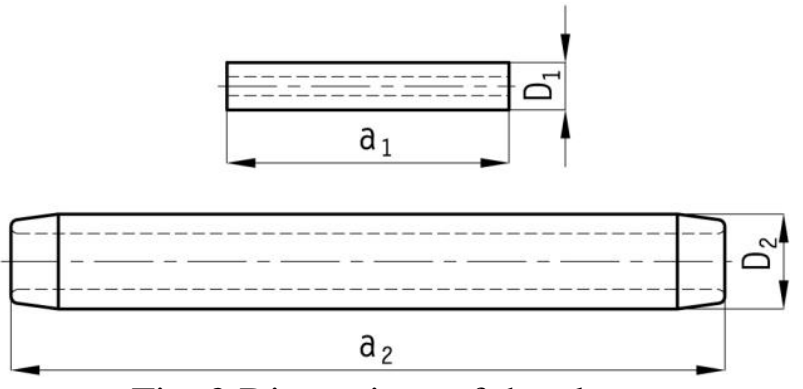

Fig. 2 Dimensions of the clamp

The pressed joint is prepared by four-point pressing of the steel part and four-point pressing of the aluminium part of the clamp (see Fig. 1) per one AlFe conductor.

\section{Model of the AlFe conductor and clamp}

The model of the AlFe 350/59, clamp and the pressing jaws were modelled in FEM program ANSYS APDL environment using solid and plane elements. Whole process of the model creation was prepared using APDL commands within user macro file.

Individual sub-volumes for wires in layers with different lay ratio and lay directions were created and meshed using sweep method. Surface contact and target elements were applied as contact pairs only on surfaces where contact may occur during the process of pressed joint creation and tensile test of the connection (e.g. surface contact elements applied on the surface of one wire in chosen layer and appropriate target elements applied only on surfaces of the adjacent wires from both sides and on the top half of the surfaces of all wires in the layer below).

Steel core and aluminium shell of the clamp were modelled as solid parts with appropriate surface contact and target elements. The solid mesh was prepared in consideration of the large plastic deformations that occur during the phase of the pressed joint creation.

Jaws of the press were modelled and meshed as rigid surfaces that can move vertically during the pressed joint creation.

Material models used for steel and aluminium components of the model were considered as bilinear material models: steel $\mathrm{E}=207 \mathrm{GPa}, v=0.3, \sigma_{\mathrm{Y}}=345 \mathrm{MPa}, \mathrm{E}_{\mathrm{t}}=1.45 \mathrm{GPa}$; aluminium: $\mathrm{E}=71 \mathrm{GPa}, v=0.33, \sigma_{\mathrm{Y}}=100 \mathrm{MPa}, \mathrm{E}_{\mathrm{t}}=0.5 \mathrm{GPa}$. All contacts used in the model were considered as contacts with friction, where these friction coefficients were used: steel-steel 0.15 , steel-aluminium 0.3 , aluminium-aluminium $0.3[9,10,11,12]$.

Additional assumptions for the model were considered:

- AlFe conductor is not prestressed $[13,14,15]$,

- influence of stranding process during conductor assembling is not considered (no additional mechanical stress in wires of the conductor),

- material properties are considered as isotropic,

- friction coefficients are considered as static and constant.

Simulation of mechanical loading of the pressed joint was divided into two phases:

- $1^{\text {st }}$ phase: pressed joint creation using jaws for steel and aluminium parts of the conductor and clamp, 
- $2^{\text {nd }}$ phase: tensile test where the conductor was axially loaded by the prescribed displacement.

Because of iterative calculation of the model with material plasticity and considerable number of contact pairs, the whole simulation was calculated using sub-modelling technique. The sub-modelling is based on simulation of sub-parts of the model with appropriate loading and boundary conditions where results are adequately evaluated for whole model of pressed joint and tensile test. The process of sub-modelling with appropriate evaluation of calculated results for whole model is based on these assumptions:

- sub-model of just one pressed joint of appropriate part of steel core of the conductor with appropriate part of steel core of the clamp achieved by one pair of jaws, see Fig. 3, was loaded by axial loading and tensile strength of such sub-part was evaluated,

- sub-models of two and three pressed joints of steel parts achieved by two or three pairs of jaws, see Fig. 4, was calculated and results of tensile strength of such sub-part was evaluated, - sub-model of just one pressed joint of appropriate part of steel core and aluminium layers of the conductor with appropriate part of aluminium shell of the clamp achieved by one pair of jaws, see Fig. 4, was loaded by axial loading and tensile strength of such sub-part was evaluated. Complexity of the model is presented by number of elements used for this submodel that was over 1.25 mil. of which almost 0.9 mil. were surface contact elements.
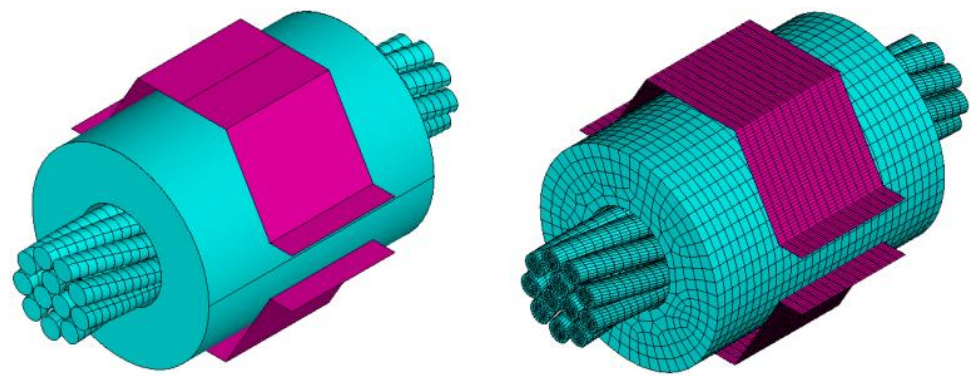

Fig. 3 Sub-model of one pressed joint of part of steel core of the conductor with part of steel core of the clamp and one pair of jaws - geometry (left), finite element mesh (right)

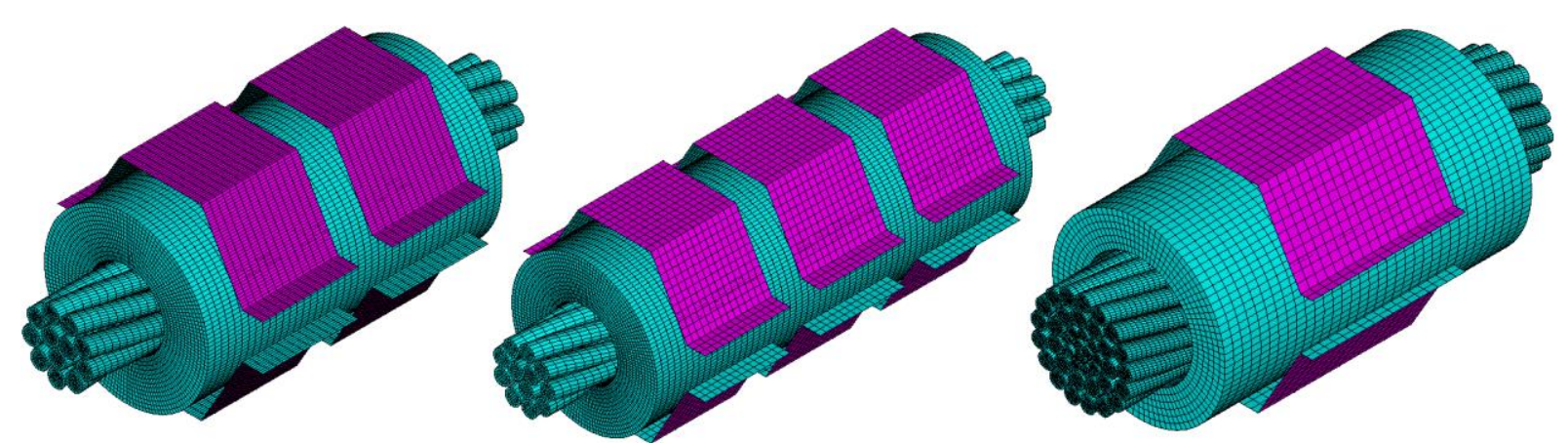

Fig. 4 Sub-model and mesh of two (left) and three (middle) pressed joints of steel parts and one pressed joint of aluminium + steel parts (right)

Individual sub-models were simulated using these loadings and boundary conditions:

- during the process of pressed joint creation, one end of the steel core (or also aluminium layers) was fixed, the second one was free,

- each jaw moved towards the counterpart (displacement for jaws for steel joints: $3.28 \mathrm{~mm}$, for aluminium + steel joints: $6.7 \mathrm{~mm}$ ) and formed the pressed joint such way that the jaws touched each other, then, jaws moved to their initial position, 
- part of the clamp was fixed on its one end and the opposite end of the conductor wires were loaded by axial displacement,

- initiation of the slip of conductor wires within the joint was monitored and appropriate axial force action was recorded and evaluated.

The process of the pressed joint creation was modelled as quasi-static analysis and the process of the tensile test was modelled as transient analysis. The results of analysed submodels in terms of mechanical von Mises stress and force action during the tensile test are shown in Fig. 5 - Fig. 7.
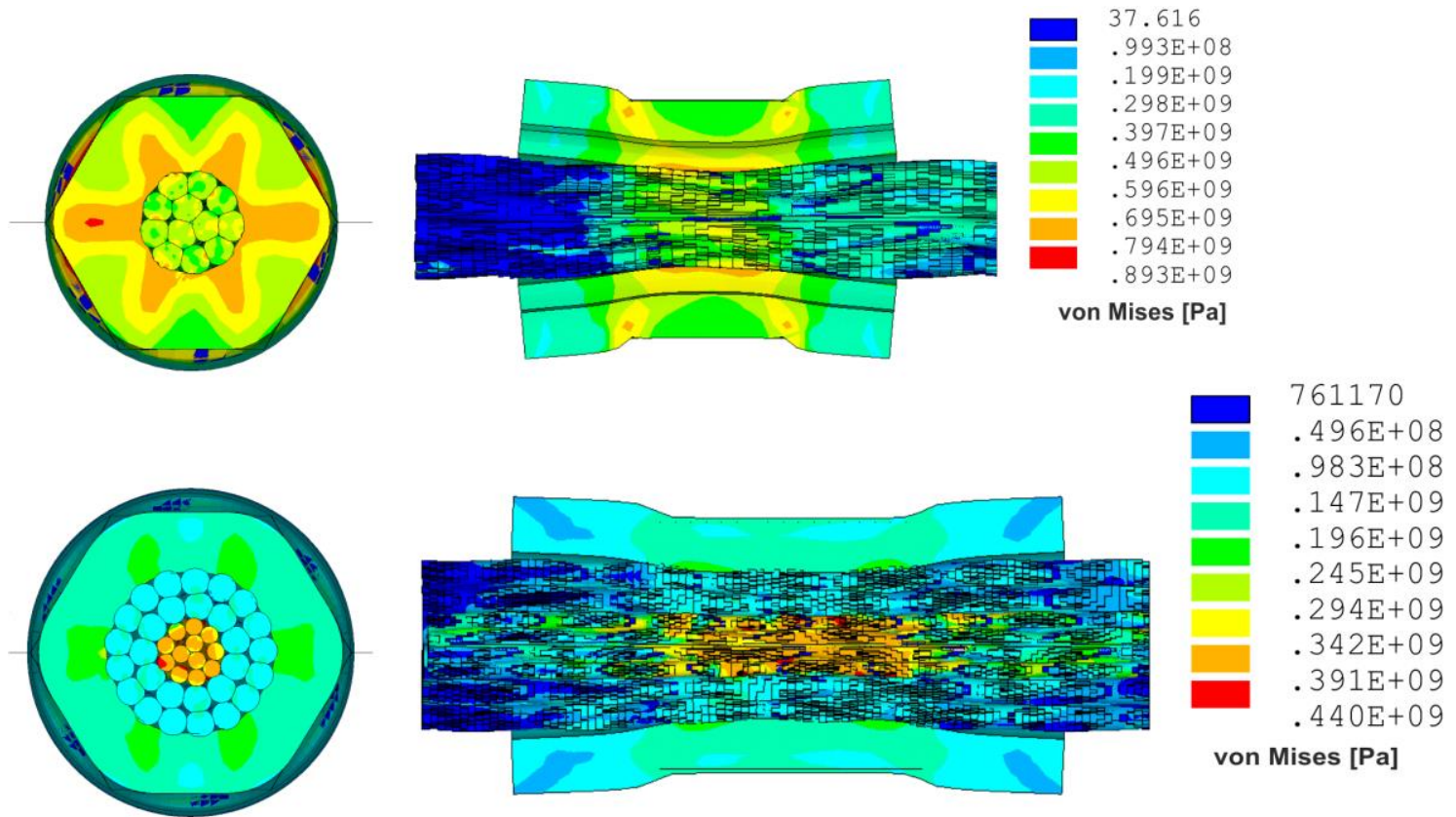

Fig. 5 Stress in model of pressed joint creation for sub-model of one pair of jaws for steel parts (top) and aluminium + steel parts (bottom) - cross-section view (left), longitudinal section view (right)
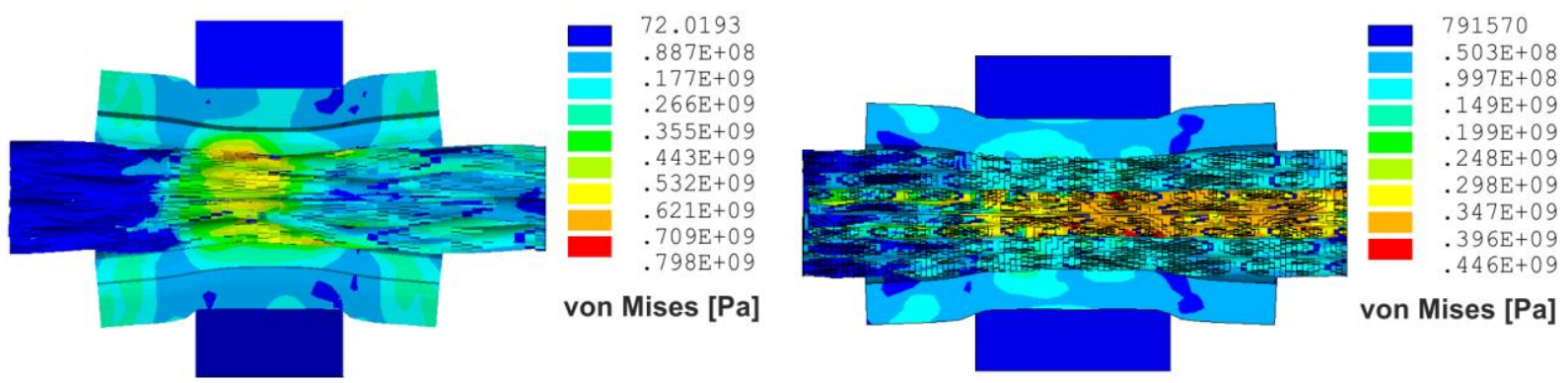

Fig. 6 Stress in model of tensile test for sub-model of one pair of jaws for steel parts (left) and aluminium + steel parts (right) - longitudinal section view 


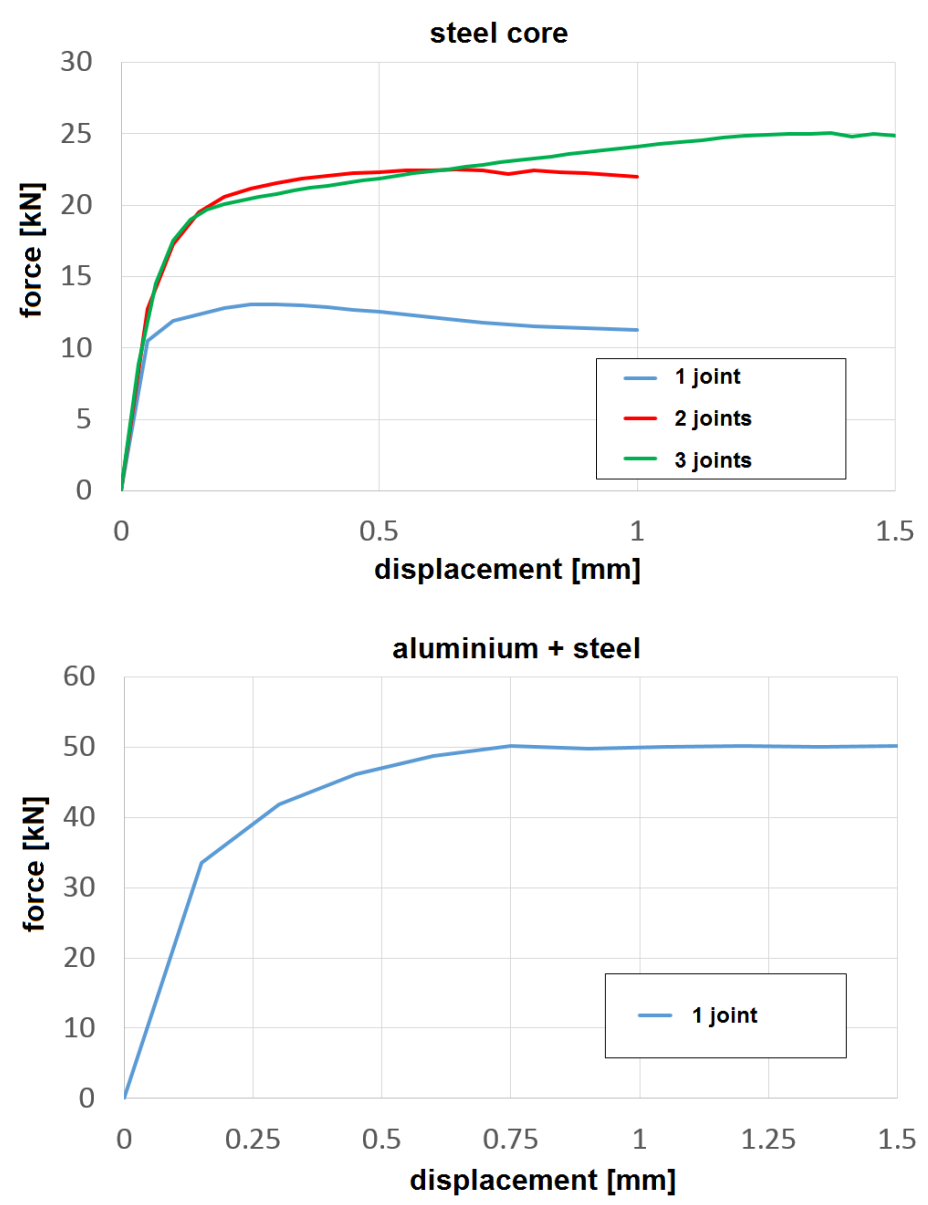

Fig. 7 Force action during the tensile test for sub-model of one, two and three pairs of jaws for steel parts (top) and one pair of jaws for aluminium + steel parts (bottom)

Results from one, two and three pressed joints of the steel parts show the dependency of the tensile strength of such joint on the axial loading during the tensile test (Fig. 7) and these results were extrapolated for four-point pressed joint of the steel parts and with the results of the summodel of one aluminium + steel pressed joint, it was also able to evaluate final tensile strength of the general pressed joint of the real conductor within the clamp.

As we can see, the tensile strength of the steel core joint saturate for three joints, so the extrapolation of the tensile strength for four joints of the steel core is assumed to remain with same value as it is for three joints, i.e. $25.3 \mathrm{kN}$. Considering the results from aluminium + steel sub-model, where tensile strength of one such joint was $50 \mathrm{kN}$ and applying the ratio between tensile strength of three steel joints and one steel joint (the ratio is 1.93) as the multiplication coefficient for four aluminium + steel joints, the tensile strength of four-point aluminium + steel joint is $96.5 \mathrm{kN}$. Final tensile strength of pressed joint of the AlFe conductor within the clamp is evaluated as sum of tensile strengths of four-point steel core joint and four-point aluminium + steel joint, i.e. $121.8 \mathrm{kN}$ and this value falls within the rated tensile strength of the AlFe conductor $(127 \mathrm{kN})$ and rated tensile strength of the clamp $(100 \mathrm{kN})$.

\section{CONCLUSION}

The results of individual sub-models of pressed joint of AlFe conductor within the clamp show, that value of force action needed for releasing the conductor from pressed joint is not linearly dependent on the number of individual pressed joints created by jaws, but it reaches saturated value. This is caused by the fact, that positions of jaws are in relative proximity and 
during the tensile test the free end of conductor within the clamp deforms its cross-section and adjusts only for the cross-section of the nearest pressed joint.

Calculated tensile strength of the connection of two AlFe 350/59 conductors within the clamp type 166635 is approx. $120 \mathrm{kN}$.

\section{ACKNOWLEDGEMENTS}

This work was supported by the Slovak Grant Agency: VEGA No. 1/0102/18, VEGA No. 1/0081/18, APVV-14-0613 and APVV-0246-12. Authors are also grateful to the HPC Centre at the STU - SIVVP project, ITMS code 26230120002.

\section{REFERENCES}

[1] Laná, s.r.o.: "Lanové vodiče", catalogue, 2010.

[2] Bekaert, a.s.: "Konštrukcia Fe duše lana AlFe 350/59".

[3] Laná, a.s.: "Konštrukcia lana AlFe 350/59".

[4] “Lisovaná spojka 166635 pre lano AlFe 6 - 350 mm2”, drawing, 1966.

[5] "Elektrovod, k.p.: Lisované spojky pre spoje namáhané t’ahom, laná AlFe”, ON 348780, p. $122-123,1986$.

[6] “Elektrovod, k.p.: Lisované spojky pre spoje namáhané t’ahom, laná AlFe”, PNE 348741, mounting instructions, pp. $54-55$.

[7] “Elba: Lisovacia hlava HL 360U s elektrickým pohonom typ 291 300”, pp. 108.

[8] "Elba: Lisovacie čel'uste pre HL 360U so šest'hranom Elba pre AlFe vodiče”, pp. 109.

[9] “FEI STU: Modelovanie priebehu teploty vodiča a jeho okolia", report, 2017

[10] “Elba: Fe spojka pre spoje namáhané t’ahom”, drawing 16-1-140, 2005.

[11] “Elba: Al spojka pre spoje namáhané t’ahom”, drawing 16-4-198, 2005.

[12] "E-konstruktér: Součinitel tření", online, 2018, https://e-konstrukter.cz/praktickainformace/soucinitel-treni

[13] Fecko, Š., Žiaran, I., Varga, L. “Elektrické siete - Vonkajšie silové vedenia”, Edičné stredisko SVŠT Bratislava, pp. 32, 1990.

[14] Hrabovský, J., Gogola, R., Murín, J., Sedlár, T. "Modeling of ice-shedding from ACSR power line", Strojnícky časopis - Journal of Mechanical Engineering 67 (1), pp. 45 - 54, 2017. DOI: $10.1515 /$ scjme-2017-0005

[15] Šlesar, P., Jančo, R. "Press-fit evaluation and study of displacement in temperature changes“, Strojnícky časopis - Journal of Mechanical Engineering 68 (1), pp. 103 - 108, 2018. DOI: $10.2478 /$ scjme-2018-0011 